\title{
The Relationships Between Preservice Teachers' Mathematical Literacy Self Efficacy Beliefs, Metacognitive Awareness And Problem Solving Skills
}

\author{
Özlem Özçakır Sümen * and Hamza Çalışıcı \\ Department of Elementary Education, Faculty of Education, Ondokuz Mayls University, \\ Samsun, Turkey
}

\begin{abstract}
The purpose of this study was to examine the relationships between metacognitive awareness, mathematical literacy self-efficacy beliefs and problem solving skills, and the effects of metacognitive awareness and mathematical literacy self-efficacy beliefs on problem solving skills. This study used a correlational survey design, and was conducted in the Faculty of Education of Ondokuz Mayis University in the 2014/15 spring semester. The sample group, selected used convenience sampling, consisted of a total of 171 prospective teachers. Data were collected using Metacognitive Awareness Inventory (Akın, Abacı \& Çetin, 2007), the Problem Solving Inventory (Şahin, Şahin \& Heppner, 1993) and Math Literacy Self-Efficacy Measurement (Özgen \& Bindak, 2008). For the data analysis, descriptive statistics, Pearson correlation, and regression analysis were used. Significant relationships were found to exist between the problem solving scores on the one hand and metacognitive awareness and math literacy selfefficacy scores on the other. In addition, the first stage of the regression analysis showed that metacognitive awareness scores are a significant predictor of problem solving skills, explaining $15 \%$ of the variation. In the second stage, it was found that metacognitive awareness and math literacy self-efficacy scores are both significant predictors of problem solving skills, together explaining $18 \%$ of the variation. This study shows that significant relationships and interactions exist between metacognitive awareness, mathematical literacy self-efficacy, and problem solving skills.
\end{abstract}

Keywords: prospective teachers; metacognitive awareness; problem solving;

mathematical literacy self-efficacy

\section{Introduction}

Problem solving is a concept that is closely related to academic achievement. Problem solving refers to individuals' efforts to reach a target when they do not have ready-made solutions, and not all learning involves problem solving (Schunk, 2011). According to Polya (1981), problem solving means finding a way out of a difficult situation, finding your way around an obstacle, and achieving a target that is not easy to reach. Problem solving is a complicated process that involves, in addition to cognitive skills, affective and behavioral characteristics (Korkut, 2002). Kuzgun (1992) defines the stages involved in problem solving,

\footnotetext{
* Department of Elementary Education, Faculty of Education, Ondokuz Mayıs University, Samsun, Turkey; ozlem.ozcakir@omu.edu.tr
} 
as the perception of the challenge, the correct identification of the problem, the implementation of a solution, and assessment. Problem solving has many benefits in the process of education, such as developing an interest in a topic among students, improving logical thinking, and increasing motivation (Chapman, 1997). Most education provided in schools is overly organized, and does not provide many opportunities for problem solving. Problem solving becomes meaningful not when there are given targets and clear guidelines to follow, in order to reach these targets, but when teachers abandon the idea of teacherdominated classrooms and encourage original and critical thinking among their students (Schunk, 2011). Various studies have examined the relationship between problem solving skills and other variables, such as academic achievement, self-efficacy beliefs, and critical thinking skills (Altunçekiç, Yaman \& Koray, 2005; Korkut, 2002; Özsoy, 2005; Saracaloğlu, Serin \& Bozkurt, 2001). Özsoy (2005) found a significant and positive relationship between primary school students' mathematics achievement and problem solving skills, and Saracaloğlu et al. (2001) found that no statistically significant relationship existed between students' problem solving skills and overall achievement. Problem solving is also related to personality traits and affective variables, such as automatic thought (Dündar, 2009; Tümkaya, Aybek \&Aldağ, 2005).

Metacognition is defined in general terms as the understanding and use of one's own cognitive processes (Reeve \&Brown, 1984). Metacognition makes it possible for a problem solver to strategically code the problem, develop a mental model, choose an appropriate strategy and plan to reach the target, while recognizing and overcoming obstacles along the way (Davidson \& Sternberg, 1998). Metacognition refers to two related types of knowledge: first, the individual should know, what skills, tactics and resources are required for the task, and second, when and how these skills, tactics and resources need to be employed for the successful completion of the task (Schunk, 2011). Metacognitive techniques help develop students' problem solving skills (Reeve \& Brown, 1984). Students need metacognitive education to understand their own learning processes, which is why metacognitive education, provided to help students monitor and control their own learning, would assist them in the evaluation and integration of strategies, to control the complex cognitive and social processes used during writing (Sitko, 1998). Metacognition is used to monitor and organize cognitive processes, such as learning, problem solving and memory, and many studies are conducted to examine the relationship between metacognition, on the one hand, and processes such as learning, memory, thinking, problem solving and reasoning on the other, and the role metacognition plays in these processes (Karakelle, 2012). For example, in a study on the use of metacognition to solve arithmetic word problems among primary school students, it was found that students who participated in the study and provided correct answers to the questions, by using their metacognitive skills, displayed the successful use of metacognitive skills, such rephrasing the problem in their own words, correctly analyzing what was given in the problem and what was asked, solving the problem using alternative strategies, transferring previous knowledge and experiences to the problem at hand, and most important of all, checking the logical consistency of the problem (Aydemir \& Kubanç, 2014). In studies on the identification of levels of metacognitive awareness among students and prospective teachers, the most common finding is high or medium levels of awareness (Baysal, Ayvaz, Çekirdekçi \& Malbeleği 2013; Özsoy \& Günindi, 2011; Tüysüz, 2013).

The concept of mathematical literacy is based on the idea that it is important and sometimes necessary for individuals to be able to master mathematical content, processes and situations encountered in the daily life, at work or at school (Özgen \& Bindak, 2011). Mathematical literacy refers to the ability of an individual to recognize and identify the role played by 
mathematics in daily life, make fact-based judgments, and to refer to and make use of mathematics when necessary, in order to lead a constructive, curious and thoughtful life (OECD, 2003). Mathematical literacy is an area of focus in PISA evaluations, and it refers not only to the knowledge of mathematical concepts and operations, but also to the ability of a person to make effective use of this knowledge to solve various problems encountered in daily life (MEB, 2012). Self-efficacy refers to a person's idea of what he or she is capable of, assessment of skills and capacities possessed, and the reflection of this assessment in behavior (Schunk, 2011). Math literacy self-efficacy refers to an individual's belief in and judgment of his or her capacity to deal with the mathematical processes, skills and situations encountered in daily life (Özgen \& Bindak, 2008). There is a strong relationship between self-efficacy in math and math performance, and self-efficacy in math is a powerful predictor of problem solving skills (Pajares \& Miller, 1994). Principles and Standards for School Mathematics, NCTM (2000) identifies the necessary components of a high quality school mathematics program. The contents and processes identified reflect the need for mathematical literacy in society, past experiences with mathematics education, and values and expectations held by mathematicians, mathematics teachers, and the general public. Various studies have been conducted to measure levels of math literacy self-efficacy among prospective teachers (Altıntaş, Özdemir \& Kerpiç, 2012; Güneş \& Gökçek, 2013; Tekin \& Tekin 2004).

Metacognitive decisions concerning each of the four categories of cognitive-metacognitive structure (orientation, organization, execution and verification) help students either to fail or succeed when solving problems (Lester, Garofalo \& Kroll, 1989). This is why problem solving skills and metacognitive awareness are related concepts. Various studies have examined the relationship mathematical literacy self-efficacy, problem solving skills and metacognitive awareness have with other variables, and reached different conclusions (Altunçekiç \& Yaman, 2005; Bakioğlu, Küçükaydın \& Karamustafaoğlu, 2015; Karakelle, 2012; Kiremitçi \& Canpolat, 2014; Özgen \& Bindak, 2011; Özsoy \& Günindi, 2011). Previous studies, however, did not establish the relationship between these related concepts and mathematical literacy self-efficacy with certainty. Thus, the present study aims to examine the relationships between metacognitive awareness, mathematical literacy selfefficacy, and problem solving skills, and the effects of the former two on problem solving skills.

\section{Method}

This study has a correlational survey design. A correlational survey is a research design that aims to identify the presence and/or level of covariation between two or more variables (Karasar, 2005). This study examines the relationships between metacognitive awareness, mathematical literacy self-efficacy, and problem solving skills.

\section{Sample}

The study was conducted during the 2014/15 spring semester at the Faculty of Education in Ondokuz Mayis University. The sample group consisted of a total of 171 prospective teachers selected used convenience sampling. Descriptive statistics concerning the sample group were as follows: Gender: There were 126 female and 45 female participants. Department: 91 participants attending the primary school teacher program and 80 attending the mathematics teacher program. Type of high school: 54 participants graduated from high schools, 82 from Anatolian high schools, 33 from teacher training high schools, and two from 
science high schools. Academic achievement (GPA): two participants had a GPA between 1.00-2.00, 101 participants between 2.00-3.00, and 69 participants between 3.00-4.00.

\section{Data collection instruments}

The data used in this study were collected using three separate scales: Metacognitive Awareness Inventory, Problem Solving Inventory, and Math Literacy Self-Efficacy Measurement. In addition, data on gender, academic achievement, program and other demographic characteristics were collected using a questionnaire developed for this purpose.

\section{Metacognitive awareness inventory}

To measure levels of metacognitive awareness among prospective teachers, the Metacognitive Awareness Inventory developed by Schraw and Dennison (1997) and adapted to Turkish by Akın et al. (2007) was used. The Metacognitive Awareness Inventory consisted of 52 five-point Likert items. The total score varied between 52 and 260. The Cronbach's alpha reliability coefficient of the scale was found to be .95 .

\section{Problem solving inventory}

To measure the prospective teachers' levels of self-reported problem solving skills, the Problem Solving Inventory developed by Heppner and Petersen (1982) and adapted to Turkish by Şahin, Şahin and Heppner (1993) was used. This scale consisted of 35 six-point Likert items. Items 9, 22 and 29 were not scored as per the instructions. Items 1, 2, 3, 4, 11, $13,14,15,17,21,25,26,30$ and 34 were reverse scored. The total score on the scale varied between 32 and 192. Higher scores on this scale indicated lower levels of perceived problem solving skills. The Cronbach's alpha $(\alpha)$ reliability coefficient of the scale was .82 .

\section{Math literacy self-efficacy measurement}

Levels of mathematical literacy self-efficacy beliefs were measured using the Math Literacy Self-Efficacy Measurement developed by Özgen and Bindak (2008). The Math Literacy Self-Efficacy Measurement was a five point Likert type scale. It consisted of a total of 25 items, four them negatively worded. The total score on the scale varied between 25 and 125 . The reliability coefficient $(\alpha)$ of the scale was .92 .

\section{Data analysis}

Descriptive statistics, Pearson correlation and regression analysis were used to analyze the data. Data analysis was carried out using SPSS 17.0 software package. Scales were distributed to the volunteering prospective teachers, and participants were given sufficient time to fill out the forms.

\section{Findings}

Table 1 reports the descriptive statistics for the scores received by prospective teachers on the Metacognitive Awareness Inventory, Math Literacy Self-Efficacy Measurement, and Problem Solving Inventory. 
Table 1. Descriptive statistics for metacognitive awareness, problem solving skills, and mathematical literacy self-efficacy scores

\begin{tabular}{llllll}
\hline & $\overline{\boldsymbol{X}}$ & SS & Min & Max & K-S \\
\hline Metacognitive Awareness & 176.78 & 31.73 & 52.00 & 267.00 & .200 \\
Problem Solving & 95.32 & 18.12 & 48.00 & 148.00 & .200 \\
Mathematical Literacy Self-Efficacy & 62.61 & 15.46 & 25.00 & 122.00 & .064 \\
\hline
\end{tabular}

Data collected from the administration of the scales to prospective teachers were analyzed to examine the relationships between the metacognitive awareness, mathematical literacy selfefficacy and problem solving skills of prospective teachers, reported in Table 2.

Table 2. Correlations between metacognitive awareness, problem solving skills and mathematical literacy self-efficacy

\begin{tabular}{llll}
\hline & $\begin{array}{l}\text { Metacognitive } \\
\text { Awareness }\end{array}$ & Problem Solving & Math Literacy Self-Efficacy \\
\hline Metacognitive Awareness & 1 & 1 & \\
Problem Solving & $-.385^{*}(\mathrm{p}=.000)$ & $.215^{*}(\mathrm{p}=.009)$ & 1 \\
Math Literacy Self-Efficacy & $-.112(\mathrm{p}=.145)$ & .006 \\
\hline
\end{tabular}

$* \mathrm{p}<.05$

As Table 2 shows, there was a negative and moderate relationship between the metacognitive awareness and problem solving skills, and a positive and weak relationship between mathematical literacy self-efficacy and problem solving skills $(\mathrm{p}<.05$; Büyüköztürk, 2012). As higher scores on the Problem Solving Scale indicate lower problem solving skills, this finding shows that higher levels of problem solving skills are associated with higher metacognitive awareness scores and lower levels of mathematical literacy self-efficacy. However, no significant relationship existed between the metacognitive awareness and mathematical literacy self-efficacy scores.

Given these findings, regression analysis was then used to identify which of the metacognitive awareness and mathematical literacy self-efficacy variables predicted problem solving skills, and how well. Problem solving skills were entered as the predicted variable in the model, and metacognitive awareness and mathematical literacy self-efficacy were entered as predictor variables. Table 3 reports the results of the regression analysis.

Table 3. Results of the regression analysis for the total score on problem solving inventory

\begin{tabular}{|c|c|c|c|c|c|c|c|c|c|}
\hline Predicted & Model & Predictor & B & Beta & $\bar{t}$ & $\begin{array}{l}\text { Standard } \\
\text { Error }\end{array}$ & $\mathbf{R}$ & $\mathbf{R}^{2}$ & $\mathbf{F}$ \\
\hline $\begin{array}{l}\text { Problem } \\
\text { Solving } \\
\text { Skills }\end{array}$ & 1 & $\begin{array}{l}\text { Metacognitive } \\
\text { Awareness }\end{array}$ & -.21 & -.38 & $-5.42^{*}$ & 15.95 & .39 & .15 & 29.46 \\
\hline $\begin{array}{l}\text { Problem } \\
\text { Solving }\end{array}$ & 2 & $\begin{array}{l}\text { Metacognitive } \\
\text { Awareness }\end{array}$ & -.20 & -.37 & & 15.72 & .42 & .18 & 18.25 \\
\hline Skills & & $\begin{array}{l}\text { Mathematical } \\
\text { Literacy Self- } \\
\text { Efficacy }\end{array}$ & .19 & .17 & $2.48 *$ & & & & \\
\hline
\end{tabular}

As Table 3 shows, metacognitive awareness is a significant predictor of problem solving 
score, and by itself, it explains $15 \%$ of the variation observed in problem solving scores. The contribution of this variable to variance is statistically significant $(\mathrm{F}=29.46, \mathrm{p}<.05)$.

At the second stage, mathematical literacy self-efficacy variable was added to the model. Metacognitive awareness and mathematical literacy sled efficacy predictor variables together explain $18 \%$ of the variation observed in problem solving skills. The two variables' joint contribution to variance is statistically significant $(\mathrm{F}=18.25, \mathrm{p}<.05)$. Metacognitive awareness is a stronger predictor of problem solving skills compared to mathematical literacy selfefficacy.

\section{Discussion and Conclusions}

Students should be raised as life long learners and educated to have problem solving and metacognitive decision making skills (MEB, 2006). Knowledge about problem solving in general, and about their own mental processes in particular, help students to become better problem solvers (Davidson and Sternberg, 1998). This study examined the relationships between problem solving skills and metacognitive awareness and mathematical literacy selfefficacy scores. It was found that problem solving skills had a significant relationship with both metacognitive awareness and mathematical literacy self-efficacy, but the relationship between metacognitive awareness and mathematical literacy self-efficacy was not significant. This finding is consistent with other findings in the literature (Bakioğlu et al. 2015; Karakelle, 2012; Kiremitçi \& Canpolat, 2014). Bakioğlu et al. (2015) found a positive, moderate and significant relationship between metacognitive awareness and problem solving skills. Karakelle (2012) examined the relationship of metacognitive awareness with perceived problem solving, the need to think, intelligence, and the effects of these three variables on metacognition, and found significant relationships between metacognitive awareness, perceived problem solving and the need to think. The findings of the present study show that higher levels of problem solving skills are associated with higher levels of metacognitive awareness, but with lower levels of mathematical literacy self-efficacy.

In the second part of the study, which used regression analysis, it was found that metacognitive awareness was a significant predictor of problem solving skills, explaining $15 \%$ of the observed variation. The second model containing both metacognitive awareness and mathematical literacy self-efficacy as predictors in the model showed that both were significant predictors of problem solving skills, together explaining $18 \%$ of the observed variation. There are other correlational studies in the literature conducted with similar variables, but the number of studies making use of regression analysis is limited. In a study which reverses predicted and predictor variables used in the present study, Karakelle (2012) found that $36 \%$ of the variation in the level of metacognitive awareness is explained by perceived problem solving ability. These findings show that levels of metacognitive awareness, problem solving skills and mathematical literacy self-efficacy beliefs of students are interrelated, and they support one another. Schunk (2011) states that teachers can develop their students' problem solving skills by activities such as rephrasing a problem in one's own words, drawing diagrams, identifying unnecessary information, identifying the method to solve the problem, and approaching the problem from different angles. These require the teaching of metacognitive techniques to students. People with metacognitive skills are more successful in planning, managing knowledge, monitoring, eliminating mistakes, and making assessments (Baysal et al. 2013). In addition, improvement of mathematical literacy selfefficacy levels and problem solving skills among students would help them achieve greater academic success, improving their quality of life. 


\section{References}

Akın, A., Abacı, R. \& Çetin, B. (2007). The validity and reliability study of the Turkish version of the Metacognitive Awareness Inventory. Educational Science: Theory \& Practice, 7(2), 655-680.

Altıntaş, E., Özdemir, A. Ş., \& Kerpiç, A. (2012). Öğretmen adaylarının matematik okuryazarlığı özyeterlik algılarının bölümlere göre karşılaştırılması. Trakya Üniversitesi Eğitim Fakültesi Dergisi, 2(2), 26-34.

Altunçekiç, A., Yaman, S., \& Koray, Ö. (2005). Öğretmen adaylarının öz-yeterlik inanç düzeyleri ve problem çözme becerileri üzerine bir araştırma (Kastamonu ili örneği). Kastamonu Ĕ̈itim Dergisi, 13 (1), 93-102.

Aydemir, H., \& Kubanç, Y. (2014). Problem çözme sürecinde üstbilişsel davranışların incelenmesi. Electronic Turkish Studies, 9(2),203-219.

Bakioğlu, B., Küçükaydın, M. A., \& Karamustafaoğlu, O. (2015). Öğretmen adaylarının bilişötesi farkındalık düzeyi, problem çözme becerileri ve teknoloji tutumlarının incelenmesi. Trakya Üniversitesi Ĕ̈itim Fakültesi Dergisi, 5(1), 22-33.

Baysal, Z. N., Ayvaz, A., Çekirdekçi, S., \& Malbeleği, F. (2013). Sınıf öğretmeni adaylarının üstbilişsel farkındalıklarının farklı değişkenler açısından incelenmesi M.Ü. Atatürk Ĕ̈itim Fakültesi Ĕgitim Bilimleri Dergisi, 37, 68-81.

Büyüköztürk, Ş. (2012). Sosyal Bilimler Iç̧in Veri Analizi El Kitabı (16. Baskl). Ankara: Pegem Akademi.

Chapman, O. (1997). Metaphors in the teaching of mathematical problem solving. Educational Studies in Mathematics, 32 (3), 201-228.

Davidson, J. E., \& Sternberg, R. J. (1998). Smart problem solving: How metacognition helps. In Hacker, D. J., Dunlosky, J., \& Graesser, A. C. (Eds.), Metacognition in educational theory and practice (pp. 47-68). New Jersey: Lawrance Erlbaum Associates, Publishers.

Dündar, S. (2009). Üniversite öğrencilerinin kişilik özellikleri ile problem çözme becerileri arasındaki ilişkinin incelenmesi. Dokuz Eylül Üniversitesi İktisadi ve İdari Bilimler Fakültesi Dergisi, 24(2), 139-150.

Güneş, G. \& Gökçek, T. (2013). Öğretmen adaylarının matematik okuryazarlık düzeylerinin belirlenmesi. Dicle Üniversitesi Ziya Gökalp Eğitim Fakültesi Dergisi, 20, 70-79.

Heppner, P.P., Petersen, C.H. (1982). The development and implications of a personal problem solving inventory. Journal of Counseling Psychology, 29(1), 66-75.

Karakelle, S. (2012). Üst bilişsel farkındalık, zekâ, problem çözme algısı ve düşünme ihtiyacı arasındaki bağlantılar. Eğitim ve Bilim, 37 (164), 237-250.

Karasar, N. (2005). Bilimsel araştırma yöntemi, kavramlar, ilkeler, teknikler (14th Edition). Ankara: Nobel Yayın.

Kiremitci, O., \& Canpolat, A. M. (2014). Beden eğitimi ve spor yüksekokulu öğrencilerinin çoklu zeka alanlarının üstbilişsel farkındalık ve problem çözme becerilerini belirlemedeki rolü. Spor Bilimleri Dergisi: Hacettepe Üniversitesi, 25(3), 118-126. 
Korkut, F. (2002). Lise öğrencilerinin problem çözme becerileri. Hacettepe Üniversitesi Eğitim Fakültesi Dergisi, 23(23), 177-184.

Kuzgun, Y. (1992). Rehberlik ve psikolojik danışma. Ankara: ÖSYM Yayınları.

Lester, F. K. Jr., Garofalo, J., \& Kroll, D., L. (1989). The role of metacognition in mathematical problem solving: A study of two grade seven classes (Final Report for National Science Foundation, Washington, D.C.). Bloomington: Indiana University. http://files.eric.ed.gov/fulltext/ED314255.pdf

MEB, (2012). PISA 2012 ulusal ön raporu. Retrieved from http://pisa.meb.gov.tr/wpcontent/uploads/2013/12/pisa2012-ulusal-on-raporu.pdf, 08.10.2015.

NCTM, (2000). Principles and Standards for School Mathematics. Retrieved from http://www.nctm.org/uploadedFiles/Standards_and_Positions/PSSM_ExecutiveSummar y.pdf, 08.10.2015.

OECD, (2003). The PISA 2003 assessment framework-mathematics, reading, science and problem solving knowledge and skills. Retrieved from http://www.oecd.org/edu/school/programmeforinternationalstudentassessmentpisa/3369 4881.pdf 20.10.2015.

Özgen, K. ve Bindak, R. (2008). Matematik okuryazarlığı öz-yeterlik ölçeğinin geliştirilmesi. Kastamonu Eğitim Dergisi, 16 (2), 517-528.

Özgen, K., \& Bindak, R. (2011). Lise öğrencilerinin matematik okuryazarlığına yönelik özyeterlik inançlarının belirlenmesi. Kuram ve Uygulamada Eğitim Bilimleri, 11(2), 10731089.

Özsoy, G. (2005). Problem çözme becerisi ile matematik başarısı arasındaki ilişki. Gazi Eğitim Fakültesi Dergisi, 25(3), 179-190.

Özsoy, G. \& Günindi, Y. (2011). Okulöncesi öğretmen adaylarının üstbilişsel farkındalık düzeyleri. Ilkogretim Online, 10(2), 430-440.

Pajares, F. \& Miller, D. (1994). The role of self efficacy and self concept beliefs in mathematical problem solving: A path analysis. Journal of Educational Psychology, 862, 193-203.

Polya, G. (1981). Mathematical discovery: On understanding, learning, and teaching problem solving (2). New York: John Wiley \& Sons.

Reeve, R. A. \& Brown, A. L. (1984). Metacognition reconsidered: Implications for intervention research (US Department of Education Technical Report No. 328). Retrieved from http://files.eric.ed.gov/fulltext/ED249484.pdf, 08.10.2015

Saracaloğlu, A. S., Serin, O., \& Bozkurt, N. (2001). Dokuz Eylül Üniversitesi Eğitim Bilimleri Enstitüsü öğrencilerinin problem çözme becerileri ile başarıları arasındaki ilişki. M.Ü. Atatürk Ĕ̆itim Fakültesi Ĕgitim Bilimleri Dergisi, 14, 121-134.

Schunk, D. H. (2011). Eğitimsel Bir Bakışla Öğrenme Teorileri [Learning Theories: An Educational Perspective] (Translated and Edited by Muzaffer Şahin) (Translation of the 5th edition) Ankara: Nobel Yayın. 
Sitko, B. M. (1998). Knowing how to write. In Hacker, D. J., Dunlosky, J., \& Graesser, A. C. (Eds.), Metacognition in educational theory and practice (pp. 93-116). New Jersey: Lawrance Erlbaum Associates, Publishers.

Sahin, N., Sahin, N. H., \& Heppner, P. P. (1993). Psychometric properties of the problem solving inventory in a group of Turkish university students. Cognitive Therapy and Research, 17(4), 379-396.

Tümkaya, S., \& İflazoğlu, U. A. (2000). Ç Ü sınıf öğretmenliği öğrencilerinin otomatik düşünce ve problem çözme düzeylerinin bazı sosyo demografik değişkenlere göre incelenmesi. Çukurova Üniversitesi Sosyal Bilimler Enstitüsü Dergisi, 6(6), 143-158.

Tüysüz, C. (2013). Üstün yetenekli öğrencilerin problem çözme becerisine yönelik üstbiliş düzeylerinin belirlenmesi. Mustafa Kemal Üniversitesi Sosyal Bilimler Enstitüsü Dergisi, 10(21), 157-166. 